\title{
Information Technology Predictor Variables and Employee Productivity in Commercial Banks
}

\author{
Pius U. Angioha*, Chidiebere U. Enukoha, Rose U. Agba, \& Gerald U. Ikhizamah \\ Department of Sociology, University of Calabar, Cross River, Nigeria
}

\begin{abstract}
The study examines the extent to which information technology predictor variables; knowledge of information technology, management support for the use of information technology; frequency of use of information technology and access to information technology relates to employees' productivity in commercial banks. The survey research method was used to select 400 samples from 8 banks using purposive, proportional and random sampling techniques. The study area is Cross River state. Structured questionnaires were used to elicit information from the population under study. The reliability of the instrument was tested using Cronbach Alpha (ranging from 0.79 and 0.91). Data were analysed using multiple regression at 0.05 confidence level. Result revealed a statistical significant joint influence of all the predictor variables (Knowledge of information technology; Management support for the use of information technology; Frequency of use of information technology and access to information technology on commercial bank employees' productivity. Based on the findings, the study recommends that Banks employ IT in a manner that meets the desired qualities of flexibility and scalability while exposing employees to regular training to keep abreast of innovations in information technology.
\end{abstract}

(C) 2020 Author(s). All rights reserved.

Keywords: Information technology predictor variables, knowledge, management support, frequency of use, access, employee productivity

\section{Introduction}

In the history of human society, information has always played a key and important role, however with societal progress and increasing innovation in science and technology, the role of information in every facet of human endeavour has become even more important.

The $21^{\text {st }}$ century has been characterized by change in all aspects of life. Change in the way we work; the homes and the way organizations are run. These changes have been attributed to progress made in information technology (Enukoha \& Angioha, 2019; Attaran, Attaran \& Kirkland, 2019). The world of work is today dynamic, creating a complex and very competitive business environment, characterized by frequently changing conditions, fluid and very unpredictable environment. These dynamics can be attributed to the changing needs of consumers and the increasing innovation of new technology. In the business environment, information technology has become a key part of work and a vital asset, its application in the right way vastly improves employee and organizational productivity (Coppersmith, 2019). Information technology improves communication and companywide collaboration. According to Gable and Raman (2010), Business organizations have incorporated information technology into their business operations, transforming service delivery and having an edge over their competition. For employees, information technology helps them to access information when they need it and exchange it within the boundaries of their

\footnotetext{
* Corresponding author.

E-mail address: xxxx@xxxxx.edu (First Author)
} 
organization as well as personal life leading to work expansion efficacy in organizational task (Jiang, 2016; Bryan, 2007).

In organizations, employees rely on information technology to communicate with customers, colleagues and management. According to Wafula (2012) in organizational settings, Information technology has affected employees workplace performance and productivity in nearly all aspects, as management, employers and employees are interconnected through information technology, helping them create a network that connects production and service delivery within and outside the organization (Angioha \& Ugal, 2019; Asli, Gilaninia \& Homayounfar, 2016). Studies have shown the relationship between Information technology and employee productivity. Oshi, Onwuka and Enyia (2016), Mutuka, and Nyaribo(2015) found that Information technology significantly influences the productivity of employees. Jahanan, Nav and Asadi (2012) found that Information technology significantly enhances efficiency, speed, skills set and develop the interest of employees in organizational goals. Ratnar and Kaur (2016) study revealed that job performance is the most impacted factor with the introduction of information technology when compared to other variables such as job satisfaction, work-life balance and health. Mutuku and Nyaribo (2015) Study found that information technology leads to increased productivity.

The Nigerian banking environment in recent time has become very competitive, bringing with it drastically changes and adopting a model that takes an international outlook (Enukoha\& Angioha, 2019). Competition has made the banks to continue to try and identify those unique innovations and technologies that will enable them to outperform their competition and meet the needs of their growing customers. Woherem (2000) argued that it is only those banks that overhaul their banking operations and develop means that improve the effectiveness and efficiency of their workers through the application modern technological innovation that can survive the growing competition in the banking industry.

Information technology in the banking industry has fostered the development of sophisticated products, created a reliable method for the control of risk, introduce new infrastructures for the market, create intermediaries for delivering banking products with relative ease while exploring other global markets(Danodu \& Osondu, 2013) Enukoha \& Angioha (2019) affirms the introduction of Information technology has significantly improved the productivity of bank employees, however the introduction of information technology has also created dependencies as virtually all Bank internal/external processes and services are dependent on IT, seen to negatively affect the efficiency of the bank employees. This study seeks to investigate the extent to which information technology predictor variables (Knowledge of Information technology, management support for the use of information technology, frequency of use of information technology and access to information technology) and Commercial Bank employee's productivity in Cross River State Nigeria.

\section{Theoretical Foundation}

The socio-technical theory was used to guide this study. The theory tries to explain the correlation between information technology adoption and it usage influences the job characteristics and productivity of employees as well as explain the interdependences between information technology and man (Bostrom \& Heinen, 1977). The theory holds that business organizations are made up of two systems; the technological system and the social system. The technological system is those innovative technologies that are used to perform tasks. The social system is human and structural elements found in all organizations. The theory holds the technological system tries to minimize the task carried out by the social system. The theory allows for the combined optimization of both systems. The fit between the social and technological system is achieved when the needs of humans are considered when implementing information technology. An imbalance in the application and utilization of the subsystem leads to damaging results such as reduced productivity.

The socio-technical systems theory best explains this study in terms of information technology adoption and its usage in banks. The adoption of information technology by banks has significantly altered the structure of work through new business process, workflow and how bank customers are attended to. The theory best explains the interrelationship between banks and their dependence on information technology. 


\section{Methods}

\subsection{Study content}

The study was carried out in eight purposively selected commercial banks in cross river state. The banks are first bank, united bank for Africa, guaranty trust bank, access bank, first city monument bank, zenith bank, union bank, and fidelity bank with 38 branches cut across the state offering retail banking, corporate banking, investment banking and asset management services to their customers. Data collected revealed staff strength of 749 cuts across selected bank branch in the state. See table 1 for the comprehensive break down of the employee population of each bank. This population covers staff from the customer services, marketing, public sectors, commercial banking and other ancillary employees of the selected banks.

Table 1 Breakdown of the population of the selected commercial banks in Cross River State

\begin{tabular}{lc}
\hline Bank & No. of Staff \\
\hline First Bank of Nigeria & 308 \\
United Bank of Africa & 54 \\
Guaranty Trust Bank & 37 \\
Access Bank & 37 \\
First City Monument Bank & 80 \\
Zenith Bank & 148 \\
Union Bank of Nigeria & 44 \\
Fidelity & 41 \\
\hline Total & 749 \\
\hline
\end{tabular}

Source: Fieldwork, 2019

\subsection{Study Design}

The survey research method was adopted for the study. The method allows for the combination of different methods of data collection and analysis. This method allows the researcher to systematically select a sample from a population and administers a standardized structured questionnaire instrument to a sample population. This is done to generate data from the selected samples on the issue under investigation through the distribution of structured questionnaires.

\subsection{Sampling strategy}

From the 748-total staff strength of the 8 purposively selected banks in cross river state, 400 sample was selected. This 400 was derived from the Taro Yamani sample determinant technique. The study adopted the purposive, proportional and simple random sampling technique. The purposive sampling technique which is a non-probability sampling technique was used to select eight banks in cross river state. These banks were selected because of their wide reach and coverage. The study then used the proportional sampling technique to select the number of respondents for each bank. This sampling technique was used as it allows a fair selection of samples according to the staff population of each bank. Finally, the simple random sampling technique was used in selecting the respondents in each bank branch. The technique was used because it gives every staff of each bank branch equal opportunity to be selected for the study see in Table 2.

Table 2 Sample distribution according to Banks

\begin{tabular}{clccc}
\hline S/N & Bank & $\begin{array}{c}\text { Bank Population } \\
\text { size }(\mathrm{N})\end{array}$ & $\begin{array}{c}\text { Proportion of } \\
\text { Staff }\end{array}$ & Sample Size (n) \\
\hline 1 & First Bank & 308 & 0.41 & 164 \\
2 & UBA & 54 & 0.07 & 29 \\
\hline
\end{tabular}




\begin{tabular}{clccc}
\hline S/N & Bank & $\begin{array}{c}\text { Bank Population } \\
\text { size }(\mathrm{N})\end{array}$ & $\begin{array}{c}\text { Proportion of } \\
\text { Staff }\end{array}$ & Sample Size (n) \\
\hline 3 & GTB & 37 & 0.05 & 20 \\
4 & FCMB & 80 & 0.10 & 43 \\
5 & Access Bank & 37 & 0.05 & 20 \\
6 & Zenith Bank & 148 & 0.20 & 79 \\
7 & UBN & 44 & 0.06 & 23 \\
8 & Fidelity Bank & 41 & 0.05 & 22 \\
& Total & $\sum \mathrm{N}=749$ & & $\sum \mathrm{n}=400$ \\
\hline
\end{tabular}

Source: Fieldwork, 2019

Table 3 Sample of Bank Branch

\begin{tabular}{|c|c|c|c|c|c|}
\hline $\mathrm{S} / \mathrm{N}$ & Bank & Branch & $\begin{array}{l}\text { Bank Branch } \\
\text { Population } \\
\text { Size (N) }\end{array}$ & $\begin{array}{c}\text { Proportion } \\
\text { of Staff }\end{array}$ & $\begin{array}{l}\text { Sample } \\
\text { Size (n) }\end{array}$ \\
\hline \multirow[t]{14}{*}{1} & FBN & Calabar Main & 75 & 0.24 & 40 \\
\hline & & Obudu & 21 & 0.07 & 11 \\
\hline & & OGoja & 20 & 0.06 & 11 \\
\hline & & Ikom & 30 & 0.10 & 16 \\
\hline & & Ugep & 18 & 0.06 & 10 \\
\hline & & Akamkpa & 18 & 0.06 & 10 \\
\hline & & Ekori & 16 & 0.05 & 9 \\
\hline & & Ekorinim & 15 & 0.05 & 8 \\
\hline & & 8 miles & 17 & 0.05 & 9 \\
\hline & & Main Avenue & 20 & 0.06 & 10 \\
\hline & & Ndidem Usang & 31 & 0.10 & 16 \\
\hline & & EPZ & 17 & 0.05 & 9 \\
\hline & & Iman & 10 & 0.03 & 5 \\
\hline & Total & & $\sum \mathrm{N}=308$ & & $\sum \mathrm{n}=164$ \\
\hline \multirow[t]{22}{*}{2} & UBA & Calabar Rd main & 18 & 0.33 & 10 \\
\hline & & Calabar Rd. & 14 & 0.30 & 8 \\
\hline & & Calabar Rd & 12 & 0.22 & 6 \\
\hline & & Ikom & 10 & 0.2 & 5 \\
\hline & Total & & $\sum \mathrm{N}=54$ & & $\sum \mathrm{n}=29$ \\
\hline & GTB & Calabar & 34 & 1.0 & 18 \\
\hline & & Ikom & 3 & 0.1 & 2 \\
\hline & Total & & $\sum \mathrm{N}=37$ & & $\sum \mathrm{n}=20$ \\
\hline & Access Bank & Calabar Rd. & 17 & 0.46 & 9 \\
\hline & & Calabar Gbogobiri & 13 & 0.35 & 7 \\
\hline & & Ogoja & 7 & 0.19 & 4 \\
\hline & Total & & $\sum \mathrm{N}=37$ & & $\sum \mathrm{n}=20$ \\
\hline & FCMB & Calabar Rd. & 40 & 0.5 & 22 \\
\hline & & New secretariat & 25 & 0.31 & 12 \\
\hline & & Ikom & 15 & 0.18 & 8 \\
\hline & Total & & $\sum \mathrm{N}=80$ & & $\sum \mathrm{n}=43$ \\
\hline & UBN & Calabar & 26 & 0.59 & 14 \\
\hline & & Akampka & 8 & 0.18 & 4 \\
\hline & & Ogoja & 10 & 0.23 & 5 \\
\hline & Total & & $\sum \mathrm{N}=44$ & & $\sum \mathrm{n}=23$ \\
\hline & Fidelity Bank & Unical & 15 & 0.36 & 8 \\
\hline & & Calabar Main & 16 & 0.39 & 9 \\
\hline
\end{tabular}




\begin{tabular}{|c|c|c|c|c|c|}
\hline $\mathrm{S} / \mathrm{N}$ & Bank & Branch & $\begin{array}{c}\text { Bank Branch } \\
\text { Population } \\
\text { Size }(N)\end{array}$ & $\begin{array}{c}\text { Proportion } \\
\text { of Staff }\end{array}$ & $\begin{array}{l}\text { Sample } \\
\text { Size (n) }\end{array}$ \\
\hline & & Ikom & 10 & 0.24 & 5 \\
\hline & Total & & $\sum \mathrm{N}=41$ & & $\sum \mathrm{n}=22$ \\
\hline \multirow{5}{*}{\multicolumn{2}{|c|}{ Zenith Bank }} & Mary Slessor & 25 & 0.17 & 14 \\
\hline & & Calabar Main & 52 & 0.35 & 27 \\
\hline & & Ikom & 23 & 0.15 & 12 \\
\hline & & Ogoja & 24 & 0.16 & 13 \\
\hline & & Chamley & 24 & 0.16 & 13 \\
\hline & Total & & 148 & & 79 \\
\hline
\end{tabular}

Source: Fieldwork, 2019

\subsection{Instrumentation and Data Collection Procedure}

The structured questionnaire was used to collect the required data for the study. The questionnaire was divided into two parts. The first part contains information on the demographic distribution of the respondents such as age, bankgrade, educational status and sex. The second required information on the variables under study. The instrument contains 15 items. The reliability of the instrument was tested using Cronbach Alpha Reliability Test. The reliability coefficient ranged from 0.79 to 0.91 and was adjudged reliable see table 4, the instrument was administered to the respondents with the help of four research assistants. Data collected was analyzed using multiple regression at 0.05 confidence level. Of the 400-administered questionnaires, only 331 respondents representing 82.7 per cent were returned without mutilation or missing out values same was used for analysis.

Table 4 Cronbach alpha reliability estimate

\begin{tabular}{lcccc}
\hline \multicolumn{1}{c}{ Variable } & $\begin{array}{c}\text { No. of } \\
\text { items }\end{array}$ & Mean & SD & $\begin{array}{c}\text { Cronbach alpha } \\
\text { value (r) }\end{array}$ \\
\hline ICT knowledge & 5 & 18.10 & 1.18 & 0.78 \\
Management support & 5 & 19.15 & 1.02 & 0.81 \\
Frequency of ICT tools used & 5 & 18.06 & 1.41 & 0.86 \\
Access to ICT tools & 5 & 17.21 & 2.42 & 0.76 \\
Bank workers productivity & 9 & 24.21 & 3.45 & 0.87 \\
Overall scale & 29 & 78.82 & 3.54 & 0.90 \\
\hline
\end{tabular}

\section{Results and Discussion}

\subsection{Study Hypothesis}

There is no significant joint relationship between knowledge of information technology; management support for the use of information technology; frequency of use of information technology and access to information technology on commercial banks employee productivity in Cross River State. The independent variable is knowledge of information technology; management support for the use of information technology; frequency of use of information technology and access to information technology, the dependent variable is employee productivity. Multiple Regression was used to analyze the data.

\subsection{Analysis}

The choice of multiple linear regression (modelling application) was to help explain the linear relationship that exists between and or among the independent variables at $\mathrm{p}<0.05$.

The regression equation is given thus: 
where:

$$
\mathrm{Yi}=\mathrm{B}_{\mathrm{o}}+\mathrm{B}_{1} \mathrm{X}_{1}+\mathrm{B}_{2} \mathrm{X}_{2}+\mathrm{B}_{3} \mathrm{X}_{3}+\mathrm{B}_{4} \mathrm{X}_{4}+\mathrm{e}_{\mathrm{i}}
$$

$\mathrm{Y} \quad$ is the predicted value of the DV (employee productivity)

$\mathrm{X}_{1} \quad=$ level of information technology knowledge

$\mathrm{X}_{2} \quad=$ management support for the use of information technology

$\mathrm{X}_{3} \quad$ = frequency of use of information technology

$\mathrm{X}_{4} \quad=$ access to information technology

Bo is the Y-intercept and

$\mathrm{e}_{\mathrm{i}} \quad$ is the error of prediction known as residuals

Table 5 Inter-correlation Matrix of the Variables

\begin{tabular}{llllll}
\hline & DV & Know & Mgt & Use & Access \\
\hline DV & 1.00 & & & & \\
Know & 0.416 & 1.00 & & & \\
Mgt & 0.170 & 0.052 & 1.00 & & \\
Use & 0.093 & 0.188 & 0.141 & 1.00 & \\
Access & 0.116 & 0.260 & 0.184 & 0.093 & 1.00 \\
Mean & 13.28 & 8.88 & 9.66 & 7.41 & 7.01 \\
SD & 5.49 & 1.28 & 2.32 & 1.09 & 0.82 \\
\hline
\end{tabular}

Key: $\quad$ DV $=$ Employee productivity

know $=$ information technology knowledge

$\mathrm{Mgt}=$ Management support for the use of information technology

Use $=$ Frequency of use of information technology tools

Access $=$ Access to information technology

Table 5 shows that multicollinearity does not occur among the four (4) predictor variables (knowledge of information technology; management support; use of information technology and access to information technology) because the zero-order correlation is less than 0.85. More importantly, none of the correlations among the independent variables is greater than 0.55 .

Table 6 Regression Model Summary of influencing employees' productivity

\begin{tabular}{|c|c|c|c|c|c|}
\hline Model & $\mathrm{R}$ & $\mathrm{R}$ square & $\begin{array}{c}\text { Adjusted R } \\
\text { square }\end{array}$ & $\begin{array}{l}\text { Std error of } \\
\text { the estimate }\end{array}$ & \\
\hline 1 & 0.460 & 0.212 & 0.202 & 4.90 & \\
\hline Source of Variables & Sum of Squares & Df & Mean square & $\mathbf{F}$ & Sig. \\
\hline Regression & 2106.978 & 4 & 526.745 & 21.881 & .000 \\
\hline Residual & 7847.892 & 326 & 24.073 & & \\
\hline Total & 9954.870 & 330 & & & \\
\hline \multirow[t]{2}{*}{ Variables } & Regression weight & & & & \\
\hline & B & Std error & Standard. Coef. & t.value & Sig. \\
\hline (constant) & 5.765 & 3.094 & & 1.863 & .063 \\
\hline Know & 1.868 & 0.222 & .439 & 8.413 & .000 \\
\hline Mgt & .476 & 0.120 & .202 & 3.963 & .000 \\
\hline Use & .077 & 0.255 & .015 & 0.301 & .763 \\
\hline Access & .226 & 0.349 & .034 & 0.649 & .517 \\
\hline
\end{tabular}

Key:

know $=$ information technology knowledge

Mgt = Management support 
Use $=$ Frequency of Use of information technology tools

Access $=$ Access to information technology

The result in Table 6 shows that the combination of all the predictor variables (knowledge of information technology; management support; use of information technology and access to information technology) are joint predictors of employee productivity. The predictors accounted for $20.2 \%$ of the variance in employee productivity.

Furthermore, the regression ANOVA revealed that there is a moderate joint contribution of the predictor variables to employee productivity $\mathrm{F}(4,326)=21.881 ; \mathrm{p}<0.05$. Based on the result, it was revealed that when all the contributor variables (knowledge of information technology; management support; use of information technology and access to information technology) when used together significantly contribute to employee productivity.

Also, Table 6 reveals the relative contributions of the four (4) predictor variables (knowledge of information technology; management support; use of information technology and access to information technology) to employee productivity as it was given by beta $(\beta)$ weight. The $\beta$ value indicates the relative contribution of each of the four predictor variables to the criterion variable (employee productivity). The higher the $\beta$ value the greater the contribution of the predictor variable. This implies that knowledge of information technology and management support for the use of information technology when used alone is an important contributory factor and motivator to employee productivity. This means that knowledge of information technology is very key to commercial bank employees to execute their daily assigned task, also management support for the use of information technology is of the essence for workers to be productive. Only two of the variables (frequency of use of information technology and access to information technology) alone are not predictors of employee's productivity.

Therefore, we can conclude that there is statistical significant joint influence of all the predictor variables (knowledge of information technology; Management support for the use of information technology; Frequency of use of information technology and access to information technology on commercial bank employees' productivity in Cross River State, Nigeria.

\subsection{Discussion of findings}

From the 331 respondents used in this study, 181 were male while 150 were female. In terms of age description, 45.6 per cent are between 34 to 41 years, 39.9 per cent were aged 26 and 33 years, 9.1 per cent were aged 18 and 25 years while 5.4 per cent were aged 42 years and above. Of the 331 respondents, 54.4 per cent were bank executives, 42.0 per cent middle management executives and 3.6 per cent were senior management executives. For educational attainment, 58.0 per cent had Bachelor (B.Sc./B.Ed./B. A) degrees, 25.7 per cent had Masters (M.Sc./M.Ed./M. A) degree and only 16.3 per cent had Higher National Diploma (HND) or its equivalent. In terms of professional qualification, 56.1 per cent had ICAN, 16.3 per cent were CIFCM certified, 14.8 per cent were NIM certified, 7.3 per cent were CIBN certified, 5.7 per cent were NIMN certified while 5.4 per cent were ACCA certified.

Result from the analysis of data revealed a statistical significant joint influence of all the predictor variables (knowledge of information technology; Management support for the use of information technology; Frequency of use of information technology and access to information technology) on commercial bank employee's productivity in Cross River State, Nigeria. The analysis revealed a moderate joint influence of the 4 predictors on employees' productivity. These predictors when analysed together accounted for 20.2 per cent of the variance in employee's productivity. Also, the regression ANOVA showed a moderate joint association of all the predictors to employees productivity $\mathrm{F}(4,326)=21.881 ; \mathrm{p}<0.05$. But when used independently, knowledge of information technology accounts for 41 per cent, management support for the use of information technology accounts for 2 per cent, access to information technology accounts for 1.16 per cent of the variance in employee productivity. But when the frequency of use of information technology was checked independently using Independent T-test, there was no relationship with employee productivity. Jointly checked, the study concludes that there is a significant joint relationship between knowledge of information technology; management support for the use of information technology; frequency of use of information technology and access to information technology on employee productivity in commercial bank in 
Cross River State. The findings from this study support Enukoha and Angioha, (2019), Coppersmith (2019), Niri (2017), whose studies revealed that information technology has a significantly positive influence on employee productivity.

\section{Conclusion and Recommendation}

The impact of information technology has been felt in all ramification of human life. In the banking industry, its impact has been enormous. There is no part of the baking process that information technology has not been felt. The findings of this study have shown that the introduction of information technology has greatly transformed banking operations especially the way bank employee's carry out their task. It has greatly improved the management process, enhanced the productivity of employees and the fast delivery of bank products. Information technology has built a foundation for innovations in the banking system. Hence, the management of banks should carry out regular training of employees to keep them abreast of the innovations in information technology as it relates to carrying out their tasks. Banks should deploy Information technology in a manner that meets the desired qualities of flexibility and scalability while maintaining a competitive edge through the provision of new and improved products and services to meet consumers ever-changing needs. Finally, in deploying ICT to improve productivity, Banks must be careful to optimize the social (workers) and technical (ICT) systems by striking a balance between both systems as an imbalance, either way, could lead to damaging outcomes like reduced productivity.

\section{References}

Angioha, P. U. \& Ugal, B. U. (2019).Information and Communication Technology and Youth Employment in Calabar Municipality, Cross River State, Nigeria. International Journal of Research and Innovation in Social Science (IJRISS), 3(2), 17-23.

Asli, S. M. G., Gilaninia, S. \& Homayounfar, D. (2016). Information Technology and Its Impact on Job Behavior. Arabian Journal of Business and Management Review (OMAN Chapter), 5(11), 1-6

Attaran, M., Attaran, S., \& Kirkland, D. (2019). The Need for Digital Workplace. International Journal of Enterprise Information Systems, 15(1), 1-23. doi:10.4018/ijeis.2019010101

Bryan, J. R. (2007), "The ambiguous relationship of ICT and organizational performance: a literature review". Critical perspectives on international business, 3 (4), pp. 306-321. https://doi.org/10.1108/17422040710832568

Coppersmith, K. (2019). How Technology Improves Workplace Productivity. Business \& Finance. https://www.business2community.com/human-resources/how-technology-improves-workplace-productivity02166853

Dawodu, B. F. \& Osondu, M. C. (2013). The Effects of Information and Communication Technology to the Growth and Development of Banking Activities in Nigeria. IOSR Journal of Electronics and Communication Engineering (IOSR-JECE). 7(3), PP 74-79

Enukoha, C. U. \& Angioha, P. U. (2019). "Management Support for the Use of Information technology in Commercial Banks in Cross River State, Nigeria: Examining Its Relationship with the Productivity of Workers", Journal of Banking and Finance Management, 2(3), pp.1-7.

Gable, G. G. \& Raman, K. S. (2010). Government Initiatives for IT Adoption in Small Businesses: Experiences of the Singapore Small Enterprises Computerisation Programme. International Information Systems 1, (1), 1, 6893.

Jahanian, R., Nav, Z. N. \& Asadi, A. (2012). The Impact of Information Technology and Communication Training on the Performance of Human Resources in Educational Organizations. World Applied Sciences Journal, 16 (6): $850-855$

Jiang, H. (2016). The Impact of Communication Technologies on Employees' Well-Being. https://instituteforpr.org/impact-communication-technologies-employees-well/

Mutuku, M. N. \& Nyaribo, W. M. (2015). Effect of Information Technology on Employee Productivity in Selected Banks in Kenya. Review of Contemporary Business Research, 4(1), pp. 49-57 
Niri, A. A. M. (2017). The Impact of Technology Factors on the Employees productivity an Empirical Study on Al Borg Cement Factory in Libya. Int J Econ Manag Sci 6: 435. doi: 10.4172/2162-6359.1000435.

Oshi, J. E. O., Onwuka, E. M. \& Enyia, C. D. (2016). Impact of ICT On Employee Productivity In Public Enterprises In Nigeria. A Study of Selected Enterprises in Rivers State. Researchjournali's Journal of Management. $4(6), 1-10$

Ratna, R. \& Kaur, T. (2016). The impact of Information Technology on Job Related Factors like Health and Safety, Job Satisfaction, Performance, Productivity and Work Life Balance. J Bus Fin Aff 5:171. doi:10.4172/21670234.1000171

Saffu, K. (2003), Improving satisfaction with bank service offerings: Measuring the contribution of each delivery channel. Managing Service Quality, 13(6), 471- 482.

Wafula, Y.O. (2012). A model for information technology in public organizations: A case study of the Kenya Revenue Authority. Information technology master's thesis, Strathmore University. Nairobi

Woherem, E. W. (2000). Information technology in the Nigerian Banking Industry, Spectrum, Ibadan. 